Association for Information Systems AIS Electronic Library (AISeL)

$5-2008$

\title{
Transition to B2B e-Marketplace Enabled Supply Chain: Readiness Assessment and Success Factors
}

\author{
Kayvan Lavassani \\ Carleton University, Kayvan@Lavassani.net \\ Bahar Movahedi \\ Carleton University, mbahar@connect.carleton.ca \\ Vinod Kumar \\ Carleton University, vinod_kumar@carleton.ca
}

Follow this and additional works at: http://aisel.aisnet.org/confirm2008

\section{Recommended Citation}

Lavassani, Kayvan; Movahedi, Bahar; and Kumar, Vinod, "Transition to B2B e-Marketplace Enabled Supply Chain: Readiness Assessment and Success Factors" (2008). CONF-IRM 2008 Proceedings. 59.

http://aisel.aisnet.org/confirm2008/59 


\title{
85F. Transition to B2B e-Marketplace Enabled Supply Chain: Readiness Assessment and Success Factors
}

\author{
Kayvan Lavassani \\ Carleton University \\ Kayvan@Lavassani.net \\ Vinod Kumar \\ Carleton University \\ Vinod_Kumar@Carleton.ca
}

\author{
Bahar Movahedi \\ Carleton University \\ mbahar@connect.carleton.ca
}

\begin{abstract}
This paper explores the development of Supply Chain Management studies and identifies three eras: Creation, Integration, and Globalization. The study then focuses on the development of supply chain management in the integration era, and specifically on the identified gap in adoption of web based processes. Electronic Market places are introduced as one of the web based tools that can help with the integration of inter and intra organizational supply chains. We proposed a transition model that organizations go through during the adoption of electronic market places. We describe our proposed transition model and highlight the importance of readiness analysis and success factors of electronic marketplace adoption.
\end{abstract}

\section{Keywords}

Supply Chain Integration, Electronic Marketplace adoption

\section{Introduction}

In studying the development of supply chain management (SCM) studies three movements of supply chain (SC) evolution could be observed which we call: SC Creation, SC integration, and SC globalization. The first era of SCM, which we name here the creation era, started in the 1980s. The concept of SC was of great importance even in the early 20th century, especially by the creation of the assembly line, however the term supply chain management was first coined by the American industry consultant, Keith Oliver, in 1982 (Persson, 1997). The worldwide recession of the late 1980s and early 1990s provided an opportunity for industry managers to reexamine value creation models and cost reduction practices throughout their organizations at the strategic level. The need for large scale changes, reengineering, downsizing driven by cost reduction programs, and "widespread study and observation of Japanese practices between 1945 and 1990" (Harland, Christine and Lamming, 1999) are the characteristics of this era of SCM (Harland, Christine and Lamming, 1999; Schonberger, 1982; Schonberger, 1987; Womack, Jones, and Roos, 1990). From the beginning, the goal of SC was "cost reduction" and at the same time "increasing the value added" throughout the organizational processes (Harland et al., 1999; Normann, 1984). However, in recent years the primary goal of SC has shifted towards customer fulfillment (Chiu and Lin, 2004; Madu and Madu, 2003). The second movement of SC, the integration era, is explained in details in the in the next section, Evolution of SCM Integration. This era started with the development of Electronic Data Interchange (EDI) systems in the 1960s and developed through the 1990s by the introduction of Enterprise Resource Planning (ERP) 
systems. It has continued into the 21st century until the present time with the expansion of internet-based, collaborative systems. This era of SC evolution is characterized by both increasing value-added and cost reduction through integration. While EDI systems were mainly concerned with inter-organizational integration, and ERP systems were mainly concerned with intra-organizational integration; internet-based solutions became concerned with both interorganizational integration and intra-organizational integration. An integrated SC provides a significant competitive advantage for the individual participant organizations (Bayraktar E., Tatoglu E., and Zaim, 2007), consequently in developed economies the enterprise-enterprise competitions have been taken over by the chain-chain competitions (Koh, Demirbag, Bayraktar, Tatoglu and Zaim; 2007; Koh and Tan, 2006).

The third movement of SCM, global SCM era can be categorized by the attention towards systems of supplier relations and the expansion of SCM over national boundaries and into other continents. Although global use of global sources in the supply chain of organizations can be traced back several decades ago (e.g. the oil industry), it was not until the late 1980s that a considerable number of organizations started to integrate global sources into their core business. By the early 1990s, internationally sourced parts and components counted for one-third of U.S. trade, reaching to $\$ 800$ billion (Long, 2006). This era is characterized by the globalization of SCM in organizations with the goal of increasing competitive advantage, creating more valueadded, and reducing costs through "sourcing globally" (Kotabe and Mol, 2006). Global sourcing is defined as "The decision-making process through which firms find and manage inputs for production in an integrated, international context in order to contribute to the creation of sustainable competitive advantage by the firm” (Lockström, 2007, p.20). What differentiates this era from the creation-era, is the attention toward "global strategic perspective" by the operational management. Kotabe and Mol, 2006 in their book entitled Global Supply Chain Management describe Global SCM as a "field of study". However, there is not a current consensus in academia as to whether global supply chain can be considered as a field of study. This study focuses mainly on the second movement of SC, the integration era.

This research is mostly focused on integration movement of supply chain management studies. In the next section we explore the concept of integration in supply chain management more explicitly.

\section{Integration Era of Supply Chain Development}

Organizations have tried for decades to achieve greater integration not only within their organization among the different functions but also with their suppliers (backward linkages) and customers (forward linkages). Timothy McNichols and Louis Brennan (McNichols and Brennan, 2004), in their study on collaborative supply networks, identified four phases of the evolution of organizational integration through electronic networks (Figure 1). Timothy McNichols and Louis Brennan (McNichols and Brennan, 2004, McNichols and Brennan, 2006) trace the roots of "supply chain technological linkages" back to EDI systems in the 1960s, when a set of standards were developed by the United Nations and the American National Standard Institute in order to facilitate the exchange of information both between and within organizations. In the 1990s many organizations started to implement ERP systems so they could integrate all organizational data across functions. This phase was more advanced than EDI in the sense that application of EDI 
did not necessarily imply changing the processes and the way of doing things. In pre-ERP systems there was only coexistence between the traditional work processes and the EDI system and information flow was fragmented by being based on functions. With the introduction of ERP systems, the traditional way of doing things was replaced with an integrated, cross-functional system. The early ERP systems were design to integrate the internal activities of the organizations.

In the late 1990s, development of virtual private network (VPN) promoted the application of web-based trading exchanges and organizations started to integrate their ERP systems with their suppliers and customers. In the 2000s, the domain of organizational integration has expanded to internet-based collaborative systems. "Just like ERP enabled collaboration between departments, the Internet has opened up never-before possibilities for widespread, real- time sharing of information among multiple trading partners” (Roshan S. Gaonkar and N. Viswanadham, 2007).

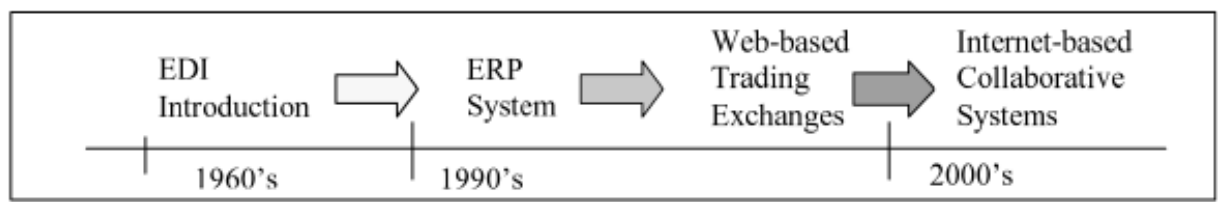

Figure 1: SC Integration Mediums

Source: Timothy McNichols and Louis Brennan (2006)

In recent years, use of the Internet as a "commerce channel", has opened up "manifold possibilities for supply chain collaboration raging from customer-driven ordering, to collaborative design and manufacturing, to real-time pricing on the demand curve” (Roshan S. Gaonkar and N. Viswanadham, 2007). Ghenniwa, Huhns, and Shen (2005) used a proposed economically motivated multi-agent e-marketplace model to show that e-marketplaces can be used in supply chain integration between organizations in order to reduce times-to-market and costs.

Organizations are finding that collaboration with their partners is vital in their competitiveness. Traditional integration platforms, such as EDI and ERP, are "not enough for the rapidly growing and changing global marketplace”. "eMarketplaces enable one-stop shopping for products by consumers, who depend on a variety of other products and services that can spread across several marketplaces. Likewise, suppliers can reach, discover, and develop new customers across various electronic marketplaces quickly with low cost. In general, electronic marketplaces offer businesses the chance to develop and enhance their most important relationships with customers and suppliers. It enables the creation and leveraging of services and supply operations in a way that seamlessly integrates business entities (customers, suppliers, partners, and competitors) in a dynamic trading community” (Ghenniwa, Huhns, and Shen, 2005). Many e-marketplaces basically B2B EMs- are oriented to support supply chains (Pucihar, A. and Podlogar, 2003). The decision of organization to enter collaborative relationships with other organizations is generally based on two types of motive: Reactive motives and Proactive motives. While proactive motives are not driven by external forces, reactive motives are caused by changes and pressures in the business environment. According to Oliver (1990), these motives, whether reactive or proactive, can be categorized into six categories: necessity, asymmetry, reciprocity, efficiency, stability, 
and legitimacy. In the next section we will provide more exploration on the concept of electronic marketplaces.

Despite the popularity of web-based technologies (including EMs) there exists a gap in the literature with regards to adoption of these integration technologies (Samaniego, Arranz, Cabezudo, 2006). In this study we will explore the properties and adoption of electronic marketplaces in SCM integration.

\section{Electronic Marketplaces}

Electronic marketplaces (EM) are new business models that are developing and changing rapidly (Mohini and Waddell, 2003). EM as a business model is built based on the notion that it can help organizations to "streamline complex business processes", "gain efficiencies”, "aggregate buyers and sellers in a single contact point”, "allow participant organizations to enjoy greater economies of scale and liquidity", "buy or sell anything easily, quickly and cost effectively", and "eliminate geographical barriers, and expand globally to reap profits in new markets" (Eng, 2004). A number of definitions for EMs are presented in the literature, which reflects how the concept is being viewed in academia. In table 1 we have presented a number of mostly cited definitions of EMs and their main focus. Traditionally, markets have three roles (Bakos, 1998): facilitating the transaction, matching buyers and sellers, and providing institutional infrastructure.

For the purpose of this study, we propose the following definition for the EMs. It uses the main points of the most cited definitions and considers the application of supply chain integration through B2B EMs: e-Marketplaces are effective and efficient collaborative Internet-based ${ }^{1}$ institutional infrastructures for inter-organizational negotiation and transaction.

This definition emphasizes the role of EMs as a collaborative enabler medium that is aligned with the application of EM in SC. The effectiveness of SC is defined by the ability of the SC to facilitate the transaction, matching buyers and sellers, and to provide institutional infrastructure (Bakos, 1998). Efficiency is defined with regards to the timeliness and cost of EMs.

\section{Transition from Traditional SCs to B2B EM enabled SCs}

In defining the EMs, we mentioned that EM is a business model. Based on the review of 22 business models, Pateli and Giaglis (2003) identified seven main components of a business model as follows: Mission, Target Market, Resources, Key Activities, Value Chain, Value Proposition, and Cost and Revenue Stream. In transition from the traditional SCs to the new B2B EM enabled SCs (e-SC), the seven main components of the business model will be affected by different degrees. Mission, target market, value proposition, and revenue stream are the relatively least affected components of the business model, since this transition deals more with the operational activities of the organization. Resources, key activities (especially those related directly to SC), value chain, and cost are the components that will be most affected by the transition, as they are tightly coupled with the SC operation.

A number of technology transition models (TTM) are presented in the literature (e.g. Briggs et al., 1998; Lefebvre et al., 2002; Briggs, 2006), however there are very few studies that discuss

\footnotetext{
${ }^{1}$ Internet-based solutions refers to e-commerce solutions which is based on the use of IP (internet protocol)
} 


\begin{tabular}{|c|c|c|}
\hline Author & Definition & Main theme(s) \\
\hline $\begin{array}{l}\text { Mccoy and } \\
\text { Sarhan } \\
(1988)\end{array}$ & $\begin{array}{l}\text { An EM separates the negotiating function from the physical transfer of the } \\
\text { product or commodity in which the market trades. It can manage buyers_and } \\
\text { sellers_offers and bids, as well as moving products directly from sellers to } \\
\text { buyers. The system is open to all buyers and sellers, regardless of their location } \\
\text { and can provide instant market information to all traders' }\end{array}$ & $\begin{array}{l}\text { Open system, } \\
\text { separation of } \\
\text { negotiation from } \\
\text { physical transfer }\end{array}$ \\
\hline $\begin{array}{l}\text { Bakos } \\
(1998)\end{array}$ & $\begin{array}{l}\text { Facilitating the exchange of information, goods, services, and payments. In the } \\
\text { process, they create economic value for buyers, sellers, market intermediaries, } \\
\text { and for society at large }\end{array}$ & $\begin{array}{l}\text { Exchange } \\
\text { facilitator }\end{array}$ \\
\hline $\begin{array}{l}\text { Bakos } \\
(1991)\end{array}$ & $\begin{array}{l}\text { An inter-organizational information system that allows the participating buyer } \\
\text { and sellers to exchange information about prices and product offerings }\end{array}$ & $\begin{array}{l}\text { Inter- } \\
\text { organizational }\end{array}$ \\
\hline $\begin{array}{l}\text { Bradley and } \\
\text { Peters } \\
(1997)\end{array}$ & $\begin{array}{l}\text { A public listing of products and their attributes from all suppliers in an industry } \\
\text { segment, and available to all potential buyers }\end{array}$ & Public listing \\
\hline $\begin{array}{l}\text { Schmid and } \\
\text { Lindemann } \\
\text { (1998) }\end{array}$ & $\begin{array}{l}\text { A media which fosters market-based exchanges between agents in all transaction } \\
\text { phases }\end{array}$ & $\begin{array}{l}\text { Agent-based } \\
\text { transaction }\end{array}$ \\
\hline $\begin{array}{l}\text { Segev, } \\
\text { Gebauer, } \\
\text { and Farver } \\
\text { (1999) }\end{array}$ & $\begin{array}{l}\text { Compared to many other electronic procurement solutions, EMs represent a } \\
\text { relatively neutral position between buyer and seller, providing services to both } \\
\text { sides of a transaction. An EM represents a virtual place where buyers and sellers } \\
\text { meet to exchange goods and services }\end{array}$ & $\begin{array}{l}\text { A neutral } \mathrm{e}- \\
\text { procurement } \\
\text { solution }\end{array}$ \\
\hline $\begin{array}{c}\text { Dai and } \\
\text { Kauffman } \\
(2000)\end{array}$ & $\begin{array}{l}\text { Function as digital intermediaries that focus on industry verticals or specific } \\
\text { business functions. They set up marketplaces where firms participate in buying } \\
\text { and selling activities after they obtain membership }\end{array}$ & $\begin{array}{l}\text { Digital } \\
\text { intermediaries }\end{array}$ \\
\hline $\begin{array}{l}\text { Mueller } \\
(2000)\end{array}$ & $\begin{array}{l}\text { Electronic markets allow buyers and sellers to exchange information about } \\
\text { product offerings and prices bid and asked }\end{array}$ & $\begin{array}{l}\text { Exchange } \\
\text { information about } \\
\text { products }\end{array}$ \\
\hline $\begin{array}{l}\text { IBM, i2, and } \\
\text { Ariba }(2000)\end{array}$ & $\begin{array}{l}\text { Commercialsites on the public Internet that allow large communities of buyers } \\
\text { and suppliers to meet and trade with each other. They present ideal structures } \\
\text { for commercial exchange, achieving new levels of market efficiency by tightening } \\
\text { and automating the relationship between supplier and buyer }\end{array}$ & $\begin{array}{l}\text { Large } \\
\text { communities }\end{array}$ \\
\hline $\begin{array}{l}\text { Kaplan and } \\
\text { Sawhney } \\
(2000)\end{array}$ & A meeting-point where suppliers and buyers can interact online & Meeting point \\
\hline $\begin{array}{l}\text { Lipis et al. } \\
\quad(2000)\end{array}$ & $\begin{array}{l}\text { An Internet-based solution that links businesses interested in buying and selling } \\
\text { related goods or services from one another. It can be distinguished from a } \\
\text { procurement or distribution system insofar as it must be neutral, taking into } \\
\text { account the interests of both buyers and sellers in its governance }\end{array}$ & $\begin{array}{l}\text { Internet-based } \\
\text { solution }\end{array}$ \\
\hline $\begin{array}{l}\text { IBM, i2, and } \\
\text { Ariba }(2000)\end{array}$ & $\begin{array}{l}\text { A many-to-many, web-based trading and collaboration solution that enables } \\
\text { companies to more efficiently buy, sell, and collaborate on a global scale }\end{array}$ & $\begin{array}{l}\text { Web-based } \\
\text { Efficient global } \\
\text { Collaboration } \\
\text { solution }\end{array}$ \\
\hline $\begin{array}{l}\text { Archer and } \\
\text { Gebauer } \\
(2000)\end{array}$ & $\begin{array}{l}\text { A virtual marketplace where buyers and suppliers meet to exchange information } \\
\text { about product and service offerings, and to negotiate and implement business } \\
\text { transactions }\end{array}$ & $\begin{array}{l}\text { Virtual place for } \\
\text { Negotiation and } \\
\text { Transaction }\end{array}$ \\
\hline $\begin{array}{l}\text { Fortino, } \\
\text { Garro, and } \\
\text { Russo } \\
(2004)\end{array}$ & $\begin{array}{l}\text { An e-commerce environment that offers new channels and business models for } \\
\text { buyers and sellers to effectively and efficiently trade goods and services over the } \\
\text { internet }\end{array}$ & $\begin{array}{l}\text { Effective and } \\
\text { Efficient Channel } \\
\text { and business } \\
\text { model }\end{array}$ \\
\hline
\end{tabular}

Table 1: Definitions of Electronic Marketplaces 
the TTM in the context of EMs. In this section, the proposed model of transition from the traditional SC to B2B EM enabled supply chain (e-SC), is described (Figure 1). According to this model the transition starts with the readiness analysis. The decision to conduct the transition is influenced by readiness factors -which we will discuss in the following section. In general the decision to carry out the transition is the function of expected value (Briggs, 2006) of EM enabled SC. The transition continues with strategic planning, facilitating the adopting of EM, and post adoption activities. The success factors play an important part in adoption phase of transition and therefore in the following sections these success factors are explored explicitly.

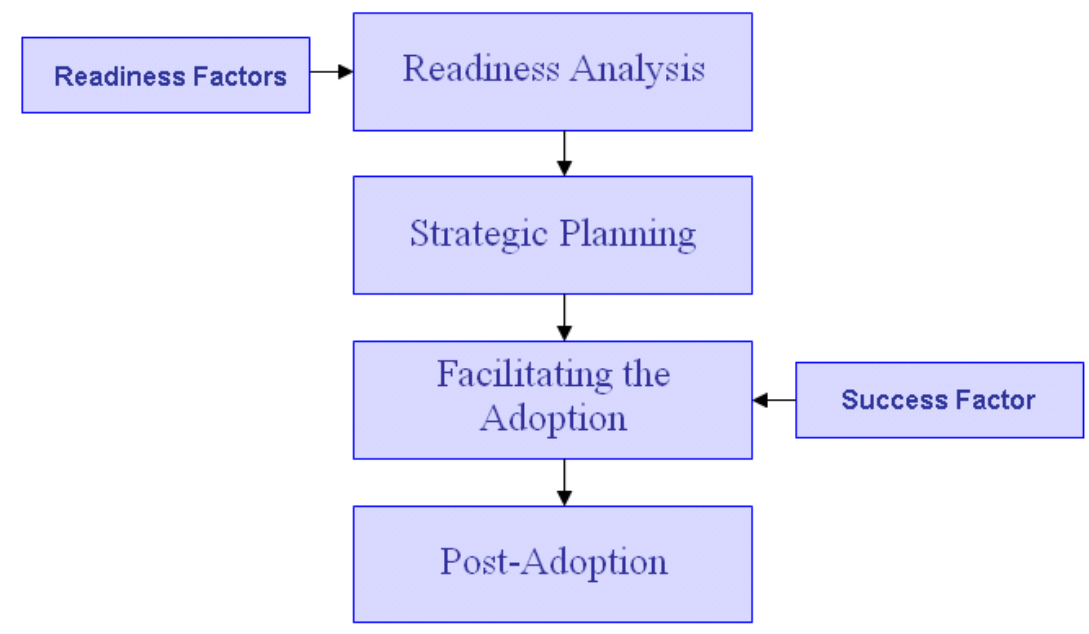

Figure 1: Supply Chain Transition Model

\section{Stage 1: Readiness Analysis}

The transition starts with the readiness analysis (Chang and Shaw, 2004; Pucihar, A. and Podlogar, 2003; Yue, 2007; McNichols and Brennan, 2006; Farid and Hananasen, 2001). The readiness of firms to engage in SC collaboration using B2B EMs stems from a readiness to adopt the EM and readiness for SC collaboration through B2B EMs. E-Readiness is influenced by the firm's organizational and environmental factors. The attention to readiness factors is the key to successful completion on this stage. An imprecise readiness analysis can cause the failure of transition. Because of the importance of this stage we have provided explicit research on readiness analysis.

\section{Factors Affecting Readiness Analysis}

For adopting B2B EMs in SCs, one of the most important issues facing managers is the degree of readiness of the adopting organizations to undergo the change process. This readiness includes two aspects: the readiness of the organizations for supply chain collaboration and the readiness of organizations to adopt the EM business model. It is important to note that there exist few empirical studies investigating the degree of readiness of organizations for SC collaboration and EM adoption. Our review of studies in this area identified two sets of organizational and environmental readiness factors. Organizational readiness factors include: SC readiness (Chang and Shaw, 2004; Dai and Kauffman, 2000), The level of eCommerce development in organization (Pucihar, A. and Podlogar, 2003), Availability of IT personnel and resources (Pucihar, A. and Podlogar, 2003), Ability to connect with business partners (Pucihar, A. and Podlogar, 2003), Knowledge and experiences about EM (Pucihar, A. and Podlogar, 2003), Corporate IT capabilities (Chang and Shaw, 2004), Perceived Technology Risk (Chang and 
Shaw, 2004), and Promotion from top management (Farid and Hananasen, 2001). The environmental readiness factors include: Supportive market condition (Chang and Shaw, 2004), Relationships with suppliers (McNichols and Brennan, 2006), and Competitiveness of the business environment (Yue, 2007).

\section{Stage 2: Strategy Planning}

The next step after readiness analysis is strategy planning. This is based on the supply chain strategy, operations strategy (Sharifi, Kehoe and Hopkins, 2006), compatibilities, and relationships (McNichols and Brennan, 2006). An important strategic decision making in this stage is clarifying the e-Marketplace strategy, and most importantly selecting the type of EM. In the second stage of transition, based on the organizational factors, characteristics of EMs and environmental factors firms should come to a decision about two critical issues of EM strategies. The first and most important decision (Markus , 2006) in this stage is whether the SC should become B2B EM enabled or not, based on their strategic goals and readiness assessment. Yue's (2007) empirical study indicates that in this stage "competitiveness of the business environment" is the most influential factors in decision making on the adoption of EMs. "Promotion from top management" and "firm characteristics" were found to be the second and third significant factors affecting the firm's decision on this issue. If the firm decided to integrate its SC with B2B EMs, the second decision is the selection of the appropriate EM type. The type of EM employed should have alignment with the strategic goals firm, operation strategy, organizational characteristics, and environmental circumstances of the firm (Sharifi, Kehoe and Hopkins, 2006). To the best of the knowledge of the author of this study there is a gap in the literature on the relationship between the organizational strategic factors and the type of EM that firms should select. A clearly defined and focused strategy that is shared by all employees and among EM participants is essential (Brunn, Jensen, and Skovgaard, 2002).

\section{Stage 3: Facilitating the Adoption}

The third stage of the transition is facilitating the adoption of EMs. Firms, EM, and the business environment have a significant role in facilitating the transition. Firms can facilitate the transition through providing the necessary technological platform (such as integrating ERP systems into the B2B EMs), training the employees, standardizing the workflow and documentation, securing top management support, and building collaborative relationships with other existing and potential EM participants. The EMs can enhance this transition through providing liquidity, critical mass, neutrality, security, trust, ease of use, reliability, value-added services, core functionality, and compatibility of EM with SCs. In addition to firms and EMs, the stimulation from other businesses - including competitors as a reactive motive - and government are influential in the successful adoption of the B2B EMs in SC integration.

\section{Success Factors of Adoption of Electronic Marketplaces}

Based on our literature review we identified 37 factors contributing to the success of adoption of EMs. We categorised these factors into three groups: organizational factors, EM factors, and environmental factors. Each are the three categories of success factors are presented here separately.

The organizational factors include: Organization's relationship with businesses (Pucihar, A. and Podlogar, 2003; (Neill and Sharon, 2004), Strategic positioning, focus (Neill and Sharon, 2004; Brunn, Jensen, and Skovgaard, 2002), Technology platform (Brunn, Jensen, and Skovgaard, 
2002), Compatibility of processes with EMs ( $\mathrm{Li}$ and $\mathrm{Li}$, 2005), Degree of workflow standardization and documentation (Yue, 2007), Extent of workflow computerization (Yue, 2007), Top management support (Yue, 2007), Product characteristics: complexity of product description and price (Fairchild, Ribbers, 2004), Asset specificity (Fairchild, Ribbers, 2004), Partnerships, access to a similar interest user community (Brunn, Jensen, and Skovgaard, 2002; $\mathrm{Li}$ and $\mathrm{Li}$, 2005), Learning costs (Fairchild, Ribbers, 2004), and Geographic location (Fairchild, Ribbers, 2004).

EM factors include: Critical mass (Neill and Sharon, 2004; Fairchild, Ribbers, 2004), Liquidity (Neill and Sharon, 2004; Ramsdell , 2000; Brunn, Jensen, and Skovgaard, 2002; Fairchild, Ribbers, 2004), Independence/Neutrality (Neill and Sharon, 2004; Fairchild, Ribbers, 2004), Security (Neill and Sharon, 2004; Fairchild, Ribbers, 2004), Trust (Neill and Sharon, 2004; Fairchild, Ribbers, 2004), Ease of use (Neill and Sharon, 2004), Reliability (Neill and Sharon, 2004; $\mathrm{Li}$ and $\mathrm{Li}$, 2005) Value-added services, throughput, support for bidding and/or negotiation (Neill and Sharon, 2004; Li and Li, 2005), Core functionality (Neill and Sharon, 2004), Facilitation of product customization ( $\mathrm{Li}$ and $\mathrm{Li}, 2005$ ), Compatibility ( $\mathrm{Li}$ and $\mathrm{Li}, 2005$ ), EM ownership, management, and governance (Ramsdell , 2000), Openness (simple EM entry and exit) (Chang and Shaw, 2004; Ramsdell , 2000; Fairchild, Ribbers, 2004), technology (Brunn, Jensen, and Skovgaard, 2002), Capturing value (Brunn, Jensen, and Skovgaard, 2002), Functionality and support (Fairchild, Ribbers, 2004), and quality of information (Fairchild, Ribbers, 2004).

The most significant environmental factors were found to be: Existence of trust between business partners (Pucihar, A. and Podlogar, 2003), Encouragement from the business environment (Pucihar, A. and Podlogar, 2003), Organization's relationship to the business environment (Pucihar, A. and Podlogar, 2003), Use of eCommerce between business partners (Pucihar, A. and Podlogar, 2003), and Market readiness (Neill and Sharon, 2004).

\section{Stage 4: Post Adoption}

The last stage is the post-adoption stage. In this stage, firms utilize their new SC and try to capture the benefits of their new B2B enabled supply chain. Yue's (2007) study shows that competitiveness of the business environment is the most important factor for firms to continue the use and expansion of the use of B2B enabled supply chain. At this stage "promotion from top management" and "firm characteristics" are not influential in the adoption and the use of B2B enabled supply chains. After review of the readiness factors and post-implementation success factors, it was identified that while readiness is mostly influenced by organizational and environmental factor, the post-implementation is mostly inflected not only with organizational and environmental factors, but also with EM factors.

\section{Conclusion}

In this paper we described the three movements of supply chain development: Creation, Integration, and Globalization. We then narrowed down our study to integration domain of SCM. The technological dimension of SC integration was explored and EM was introduced as one of the tools for integration of organizational SC and inter organizational collaboration. We should note that EMs are only one of the means among other tools which can facilitate the integration of 
inter and intra-organizational supply chain. EMs are not to replace any previously used integration tools, rather they are to integrated with the existing organizational processes and enable organizations to create more value throughout the supply chain. We identified that there are very few studies exploring the adoption of EMs for supply chain integration. In an effort to address this issue we reviewed the technology transition models and proposed a transition model for successful adoption of EMs in organizational supply chains.

We paid significant attention to the readiness analysis and adoption stages of transition, while emphasising that transition to B2B enabled supply chains does not end with adoption. However because of the limited studies in this area, the readiness analysis and success factors are mostly developed based on the review of the literature on general forms of EM implementation -and not merely adoption of EM in SCM. Further studies are required to validate and (if required) to refine this transition model.

\section{References}

Archer, N.; Gebauer, J. "Managing in the Context of the New Electronic Marketplace”. Proceedings 1st World Congress on the Management of Electronic Commerce, Hamilton, Ontario, Canada, January 19 - 21, 2000.

Bakos, J. Y. “A strategic analysis of Electronic Marketplaces”. MIS Quarterly, 1999, Vol. 15 No. 3, pp. 295-310

Bakos, J.Y. "The Emerging Role of Electronic Marketplaces on the Internet,"Communications of the ACM, 1998, 41, 8, 35-42.

Bayraktar E., Tatoglu E., and Zaim S., “The impact of Supply Chain Management Practices on Performance of SMEs”. Industrial Management \& Data Systems, Vol. 107 No. 1, 2007 pp. 103-124

Bradley III, D.B., Peters, D., “Electronic Marketplaces: Collaborate If You Want To Compete”. 42nd World Conference International Council for Small Business, San Francisco, June 1997.

Briggs R. O., Adkins M., Mittleman D., Kruse J., Miller J., Nunamaker J. F. (1998) A technology transition model derived from Field Investigation of GSS use aboard the U.S.S. CORONA. Journal of Management Information Systems, Volume 15 , Issue 3

Briggs Robert O. (2006) The Value Frequency Model: Toward a Theoretical Understanding of Organizational Change. Proceedings of International Conference of Group Decision and Negotiation (GDN), 2006, Karlsruhe, Germany.

Brunn P., Jensen, M. and Skovgaard, J., "E-marketplaces: crafting a winning strategy”, European Management Journal, Vol. 20 No. 3, 2002, pp. 286-98.

Chang and Shaw, "Developing the Readiness Index of IT-enabled Supply Chain Collaboration". Center for IT and e-Business Management. University of Illinois and Urbana Champaign. 2004, URL:

Chiu M. and Lin G., "Collaborative supply chain planning using the artificial neural network approach”. Journal of Manufacturing Technology Management, Volume 15 • Number 8 • $2004 \cdot$ pp. 787-796

Dai, Q. and Kauffman, R. "Business models for Internet based e-procurement systems and B2B electronic markets: An exploratory assessment”, Proceedings of the 34th Hawaii International Conference on Systems Science, 2000. 
Dai, Q. and Kauffman, R., “To be or not to B2B? an evaluative model for e-procurement channel adoption”, Working Paper, Carlson School of Management, University of Minnesota, Minneapolis, MN, 2000.

Eng, Teck-Yong “The role of e-marketplaces in supply chain management”. Industrial Marketing Management 33, 2004, 97-105.

Fairchild, A. M., Ribbers, P. M. A., and Nooteboom, A. O., “A Success Factor Model for Electronic Markets: Defining Outcomes Based on Stakeholder Context and Business Process”. Business Process Management Journal, 10(1), 2004, pp. 63-79.

Farid and Hananasen, “B2B E-commerce: Value Chain Transformation, Enablers and Barriers, Technology, Privacy and Security”. MIT Masters thesis, 2001

Fortino, G. and Russo, W. “A Statecharts-based Software Development Process for Mobile Agents”. Information and Software Technology, 2004.

Ghenniwa Hamada, Huhns Michael, and Shen Weiming, “eMarketplaces for Enterprise and Cross Enterprise Integration”. Data \& Knowledge Engineering, Vol. 52, 2005, pp. 33-59.

Harland, Christine M. and Lamming, Richard C., "Developing the Concept of Supply Strategy”. International Journal of Operations \& Production Management, Vol. 19 No. 7, 1999, pp. 650-673.

IBM, i2, \& Ariba, A. M. “E-marketplaces Changing the Way we do Business”. Available at: www.ibm-i2-ariba.com, A whitepaper published by Ariba and date accessed May 2000.

Kaplan, Robert S. \& Sawhney, Mohanbir "B-to-B e-commerce hubs: towards a taxonomy of business models”, Harvard Business Review, 79(1), 2000, 97-100.

Koh S.C. Lenny, Demirbag M., Bayraktar E., Tatoglu E. and Zaim S., "The impact of supply chain management practices on performance of SMEs”. Industrial Management \& Data Systems, Vol. 107 No. 1, 2007 pp. 103-124

Koh, S.C.L. and Tan, K.H., "Operational Intelligence Discovery and Knowledge Mapping approach in a Supply Network with Uncertainty”, Journal of Manufacturing Technology Management, Vol. 17 No. 6, pp. 687-99.

Kotabe M., and Mol JM. J., “Global Supply Chain Management”. Edward Elgar Publishing Limited, 2006.

Lefebvre Louis A, and Lefebvre Elisabeth (2002). E-commerce and virtual enterprises: issues and challenges for transition economies. Technovation 22 (2002) 313-323

Li J. and Li L., “On the Critical Success Factors for B2B E-marketplace”. Proceedings of the 7th international conference on Electronic commerce. 2005, pp. 119 - 122 ISBN:1-59593-1120

Lipis, L.J., Villars, R., Byron, D., Turner, V. "Putting Markets into Place: An e-Marketplace Definition and Forecast”. 2000, Downloadable from website http://www.idc.com.

Lockström, Martin “Low-Cost Country Sourcing: Trends and Implications”, Published 2007 DUV. ISBN 3835006924

Long D., “International Logistics: Global Supply Chain Management”. Springer; $1^{\text {st }}$ edition, 204, ISBN 1402074530

Madu C. N., and Madu A. A., “E-quality in an integrated enterprise”. The TQM Magazine. Jun 2003 Volume: 15 Issue: 3 Page: 127 - 136

Markus, M. Lynne, "Secret to integrate with your business partner-Maximize the benefits for them AND maximize the benefits for yourself”, CIO Insight, Jul-2006

Markus, M. Lynne, "Secret to integrate with your business partner-Maximize the benefits for them AND maximize the benefits for yourself”, CIO Insight, Jul-2006 
McCoy, J.H., Sarhan, M.E., “Livestock and Meat Marketing”. AVI Book Publishing, 1988.

McNichols, T.J. and Brennan, L., "Can electronic data interchange measure up to a collaborative supply chain?” in Hosni Y.A. and Khalil T.M. (Eds). Internet Economy: Opportunities and Challenges for Developed and Developing Regions of the World, Oxford: Elsevier Ltd., 2004 pp.27-42.

McNichols, T.J. and Brennan, L., "Evaluating partner suitability for collaborative supply networks”. International Journal of Networking and Virtual Organizations, 2006 - Vol. 3, No. 2 pp. 220 - 237

Mohini Singh and Dianne Waddell “E-Business Innovation and Change Management”. Publisher: IGI Global, September 2003, ISBN-13: 978-1591401384

Mueller, R.A.E., (2000). Emergent E-Commerce in Agriculture. Agriculture Issues Center, AIC Issues Brief (14), December.

Neill Mark and Purchase Sharon, “An Asian Perspective on Airline Industry eMarkets”, Australasian Marketing”, Australasian Marketing Journal, 2004, 12, 1.

Normann, R., "Service Management: Strategy and Leadership in Service Business”, John Wiley and Sons, New York, NY, 1984.

Oliver C., "Determinants of inter-organizational relationships: Integration and future directions". Academy of Management Review, Vol. 15:241-265, 1990.

Pateli, A. and Giaglis, G. “A Framework for Understanding and Analysing e- Business Models' (Contribution to the 16th Bled Electronic Commerce Conference), 2003, URL: http://www.eltrun.gr/papers/pateli_giaglis_bled2003.pdf, Download 2005-07-02.

Pateli, A. and Giaglis, G., “A Framework for Understanding and Analyzing e- Business Models”, 16th Bled Electronic Commerce Conference, 2003 URL: http://www.eltrun.gr/papers/pateli_giaglis_bled2003.pdf

Persson J., “A Conceptual and Empirical Examination of the Management Concept Supply Chain Management”, Licentiate Thesis, Lulea University of Technology, Lulea, 1997.

Pucihar, A. and Podlogar, M., "Influence of business environment on successful entering emarketplace: case in large organizations in Slovenia”., Research works proceedings, Vol. 10, 2003, Economics set. Ostrava: Technical University of Ostrava, Faculty of Economics, 371379.

Ramsdell, G., "The real business of B2B", The McKinsey Quarterly, No. 3, 2000, pp. 175-6

Roshan S. Gaonkar and N. Viswanadham, “Analytical Framework for the Management of Risk in Supply Chains”, IEEE Transactions on Automation Science and Engineering, VOL. 4, NO. 2, APRIL 2007

Samaniego M. Jose, Arranz Ana M. , Cabezudo Rebeca S. J. "Determinants of internet use in the purchasing process”, Journal of Business \& Industrial Marketing Volume 21 Number 32006 pp. 164-174.

Schmid, B.F. and Lindemann, M.A. “Elements of a reference model for electronic markets”, 31st Hawaii International Conference on System Sciences, IEEE Computer Society Press, Los Alamitos, CA, 1998, pp. 193-201.

Schonberger, "World Class Manufacturing: The Lessons of Simplicity Applied”, Free Press, New York, NY, 1987.

Schonberger, R.J., “Japanese Manufacturing Techniques: Nine Hidden Lessons in Simplicity”, Free Press, New York, NY, 1982.

Segev, A., Gebauer, J., and Farver, F “Internet based Electronic Markets”, Electronic Markets, 1999, Volume 9, Number 3, pp 138-146 
Sharifi H, Kehoe D. F. and Hopkins J., "A classification and selection model of e-marketplaces for better alignment of supply chains”. Enterprise Information Management Journal, 2006, Vol. 19 issue 5 pp 483-503

Womack, J., Jones, D. and Roos, D., “The Machine that Changed the World”, Rawlinson Associates, New York, NY, 1990.

Yue, Chian-son, "What Drives Enterprises to trading via B2B e-Marketplaces?” Journal of Electronic Commerce Research, VOL 8, NO.1, 2007. 